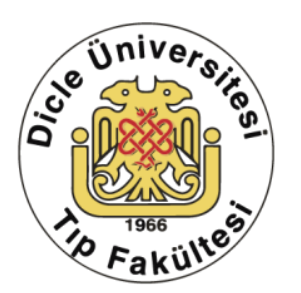

\title{
Stria longitudinalis medialis ve lateralis'in morfolojik olarak incelenmesi
}

\author{
İsmet Demirtaş' ${ }^{1}$ Kubilay Doğan Kılıç², Yiğit Uyanıkgil ${ }^{3}$, Canan Yurttaş ${ }^{4}$ \\ 1 İstinye Üniversitesi, Tıp Fakültesi, Anatomi Anabilim Dall, İstanbul, Türkiye ORCID: 0000-0001-5789-6985 \\ 2 Ege Üniversitesi, Tıp Fakültesi, Histoloji ve Embriyoloji Anabilim Dall, İzmir, Türkiye ORCID: 0000-0002-9484-0777 \\ 3 Ege Üniversitesi, Tıp Fakültesi, Histoloji ve Embriyoloji Anabilim Dal, İzmir, Türkiye ORCID: 0000-0002-4016-0522 \\ 4 Ege Üniversitesi, Tıp Fakültesi, Anatomi Anabilim Dal, İzmir, Türkiye ORCID: 0000-0001-8913-6921
}

Geliş: 20.05.2019; Revizyon: 04.07.2019; Kabul Tarihi: 08.10.2019

\section{Öz}

Amaç: Bu çalışmada, bilinen bazı boyama yöntemlerinin modifiye edilerek stria longitudinalis medialis ve lateralis'in histo-morfolojik olarak incelenmesi ve elde edilecek bulguların bundan sonra yapılacak olan benzer çalışmalara ışık tutması amaçlanmıştır.

Yöntemler: Çalışmamızda, \%10'luk formaldehit ile tespit edilmiş, makroskobik patolojisi gözlenmeyen, doku bütünlügü bozulmamış yetişkin kadavra beyin hemisferleri arasından elde edilen dokular kullanıldı. Beş kadavra beyninden alınan örneklerden üçü uygun boyama metoduna ulaşabilmek amacıyla kullanıldı. Doku fiksasyon metodu, Hematoksilen-eozin boyama metodu ve Luxol fast blue boyama metodu uygulandı.

Bulgular: Histolojik olarak ilk defa corpus callosum (CC), indusium griseum (IG) ve stria longitudinalis (SL) aynı görüntü üzerinde tespit edildi. SL'in lifleri, vasküler ve morfolojik yapısı belirtildi.

Sonuç: Umuyoruz ki, SL ile ilgili histolojik, immünohistokimyasal ve anatomik yaklaşımlar ışığında yaptığımız bu girişim, bu konu üzerindeki bazı karanlık yönleri aydınlatacaktır. Böylece bizden sonra SL üzerinde çalışacak araștırmacıların istifadesine sunulmak üzere akademik bir hafıza oluşturacaktır.

Anahtar kelimeler: stria longitudinalis, histolojik boyama yöntemleri, kadavra beyni.

DOI: $10.5798 /$ dicletip

Yazışma Adresi / Correspondence: Canan Yurttaş, Ege Üniversitesi Tıp Fakültesi Anatomi Anabilim Dalı, İzmir, Türkiye

e-mail: canan.yurttas@gmail.com 


\title{
Morphologic study of medial and lateral longitudinal stria
}

\begin{abstract}
Objectives: The aim of the study is to investigate medial and lateral longitudinal striae histologically and morphologically by some modified staining techniques. The findings of this study may shed some light on future studies.

Method: In our study, adult cadaveric brain hemispheres that fixed with 10\% formaldehyde solution, without macroscopic pathology and unaffected tissue integrity were used. Three of the samples taken from five cadaver brains were used to reach the proper staining method. Tissue fixation method, Hematoxylin-eosin staining method and the Luxol fast blue staining method was applied.

Results: Histologically, corpus callosum (CC), indusium griseum (IG) and longitudinal stria (LS) were detected on the same image for the first time. The fibers and vascular and morphological structures of the LS-ae were indicated.

Conclusion: We hope that this initiative in the light of histological, immunohistochemical and anatomic approaches to LS will illuminate some of the dark aspects about this subject. Thus, this will create an academic memory for researchers who studying on LS.
\end{abstract}

Keywords: longitudinal stria, histological staining methods, cadaver brain.

\section{GİRIș}

Corpus callosum (CC), fissura sagittalis superior'un derininde lokalize olan ve beyin hemisferlerindeki aynı fonksiyonel özelliğe sahip kortikal bölgeleri birbirine bağlayan en büyük komissural yoldur. CC, ön kısmindan arkaya doğru sırasıyla; rostrum corporis callosi (rCC), genu corporis callosi (gCC), truncus corporis callosi (tCC) ve splenium corporis callosi (sCC) olmak üzere dört bölüme ayrilır. Fissura sagittalis superior belli bir miktar ayrllarak beyin hemisferleri birbirinden uzaklaştırıldığında, CC'un üzerinde ince bir gri cevher tabakası olan indusium griseum (IG) görülmektedir. Indusium griseum'un üzerinde ve içerisine gömülü vaziyette arkadan öne doğru uzanan, miyelinli lifler tarafından oluşturulan iki ince şerit bulunmaktadır; stria longitudinalis medialis (SLM) ve stria longitudinalis lateralis (SLL) ${ }^{1-4}$.

SLM'ler orta hatta, IG boyunca uzanırlar. Daha güçlü ve dikkat çekici bir şekilde işaretlenmiş olup, karşı taraftaki eşi ile belli belirsiz bir orta açıklık ile ayrılmıştır. SLL, gyrus cinguli örtüsünün altında, birbirine daha uzak ve diş tarafta sulcus corporis callosi'nin dibinde yerleşmiştir. Beyaz cevherden meydana gelen bu iki ince lif demeti area septalis'e kadar uzanmaktadır ${ }^{1,2,5-8}$. İnsanlardaki stria longitudinalis (SL)'in boyut ve oluşum açısından morfolojik değişkenliği, kaynak taramasında ulaşılabilen mevcut verilere bakıldığında, tam olarak bilinmemektedir. Sadece bir şey net olarak biliniyor; SLM, SLL'e nazaran midsagittal düzleme daha yakın ve çok daha dikkat çekicidir9.

Stria longitudinalis'ler bilimsel olarak ilk defa yaklaşı 300 sene önce, İtalyan bir doktor olan, Giovanni Maria Lancisi tarafindan tanımland ${ }^{10,11}$. Sağ ve sol beyin hemisferlerindeki aynı işlevsel özellikleri taşıyan eşit merkezleri birbirine bağlayan en büyük ve en kalın kommissural yolun CC olduğu bilinmektedir. Buradan yola çıkarak Lancisi, SLM'in, CC'un anterior parçası ile fornix'in columna anterior'u arasinda ve CC'un posterior parçası ile thalamus arasında, ruhun yerleşkesi ile periferal organlar arasında bir bakıma bağlantı olduğunu belirtti. Lancisi, SLM'i ruhun (veya muhtemelen bilinç) akıntı halinde gitmesi için potansiyel bir 'yol' ve nihayetinde ruhu vücuda bağlayan bir köprü olarak yorumladi ${ }^{6}$. 
Limbik sistem gibi evrimsel olarak daha yaşlı beyin sistemleri, duygusal işlemenin temel özelliklerini yerine getirmekte ve kompleks davranışları düzenlemek için filogenetik olarak daha yeni beyin sistemleri için uygun ve motivasyonel bilgi sağlamaktadır. Duygu ve motivasyondaki limbik sistem işlevinin anlaşılması, bu alt sistemlerin dağıtılmış bir limbik ağın uzatılmıș bileșenleri olarak tanınması ve karakterize edilmesini gerektirir $^{12}$. Nieuwenhuys ve ark. (2007), gyrus supracallosalis olarak da bilinen, IG ve SL'i "daha büyük limbik sistem"in bölümleri olarak yorumlamıștır'13. Buradan yola çıkarak, SL ve konumsal olarak yakın ilişki içinde bulunduğu CC ve IG'un anatomik özelliklerinin daha detaylı olarak incelenmesinin faydalı olacağı düşünülmektedir.

IG'un ve büyük oranda fonksiyonel özellikleri hakkında neredeyse yok denecek kadar az bilgiye sahip olduğumuz SL'in anormallikleri, şizofreni, obsesif-kompulsif bozukluğu, Tourette sendromu, otizm ve dikkat eksikliği ile birlikte olan hiperaktivite rahatsızlığını da içeren birçok nöropsikiyatrik hastalıkları ortaya çlkarabilir ${ }^{14}$. Yine, CC cerrahisi veya beyin tümörleri, anevrizmalar, beynin dejeneratif hastalıkları ve nadiren inme sonrası ortaya çlkan ve anormal istemsiz hareketle ilişkili olan Alien hand sendromu (Yabancı el sendromu)'nun tam olarak sebebi tespit edilmiş değildir. CC, IG ve SL'in hangisi veya hangilerinin bu hastalığın oluşmasında asıl rol sahibi olduğu henüz bilinmemektedir ${ }^{15}$. Eğer SL'in histolojik yapısı hakkında, kadavra beyin hemisferlerinden elde ettiğimiz tespit edilmiş dokular kullanılarak, yeni ve ayırt edici bilgiler elde edilirse, SL'in fonksiyonları üzerindeki gizemin kaldırılmasına önemli bir katkıda bulunulmuş olur.

Bu çalışmadaki amaç, beyin dokusundan alınan örneklerin gerekli histolojik prosedürler uygulandıktan sonra Hematoksilen \& Eosin, Luxol Fast Blue ile histolojik ve nörofilament (NF) ile immünohistokimyasal olarak boyanarak ışı mikroskobunda incelenmesidir. Buradan yola çıkarak SL'in limbik sistem ve bileşenleriyle var olduğu düşünülen fonksiyonel ilişkisinin sağlam temellere dayandırılması için histo-morfolojik özelliklerinin ortaya çlkarılmasının sağlanmasıdır. Bunun sonucunda da elde edilen veriler ışığında, özellikle histolojik ve fonksiyonel olarak çok bakir bir yapı olan, SL hakkında mevcut bilgilerin genişletilip bilimsel yerinin araştırılıp bulunmasıdır. Aynı zamanda kullandığımız bu histolojik boyaların mevcut olan uygulama protokollerinin mevcut çalışmada revize edilip edilemeyeceğinin tespit edilmesidir.

\section{YÖNTEMLER}

$\mathrm{Bu}$ çalışmada Ege Üniversitesi Tıp Fakültesi Anatomi Anabilim Dalı'ndan temin edilip, $\% 10^{\prime} l u k$ formaldehit ile fikse edilmiş, makroskobik patolojisi gözlenmeyen, doku bütünlügü bozulmamış yetişkin kadavra beyin hemisferleri arasından elde edilen dokular kullanıldı. 5 kadavra beyninden alınan örneklerden 2'si uygun boyama metoduna ulaşabilmek amacıyla kullanıldı. Çalışma, geriye kalan 3 beyinden elde edilen doku örnekleri üzerinden sürdürüldü. CC'un yerinin tayin edilmesi esnasında Bahuleyan ve ark.'nın (2011) yapmış oldukları teknik çalışmadan faydalanıldı. Bahuleyan ve ark.'nın yapmış oldukları çalışmada, CC, falx cerebri'nin alt kenarının birkaç milimetre alt tarafında görüldü. CC'un üst yüzeyi, onu besleyen küçük kallosal arterler ile birlikte parlayan bir beyaz yapı olarak tespit edildi (Şekil 1a-1b) ${ }^{16}$. İncelenen beyin, kesme platformu (suntalam) üzerine uygun pozisyonda yerleștirildi. Beyin bıçağı ile fissura longitudinalis superior'dan yaklaşık $1 \mathrm{~cm}$ kadar derine inecek şekilde transvers olarak kesildi. Daha sonra SLM ve SLL'in bulunduğu genu corporis callosi, truncus corporis callosi ve splenium corporis callosi bölgelerinden 4 numaralı bistüri kullanılarak 1 cm2'lik düzgün kesitler alındı. Bu aşamaların hepsinde etik kurallara ve genel diseksiyon 
tekniklerine dikkat edildi. Yapılan araștırmada SL'i fotoğraflamak için profesyonel fotoğraf makinesi kullanılıp, hafıza kartıyla bilgisayara aktarılma sağlandı (Şekil 1a-1b). Tanımlayıcı olan bu çalışmaya, 17-2/8 karar numaralı ve 23.02.2017 tarihli Ege Üniversitesi Tıp Fakültesi Klinik Araştırmalar Etik Kurulu kararı ve izniyle başlanıldı.
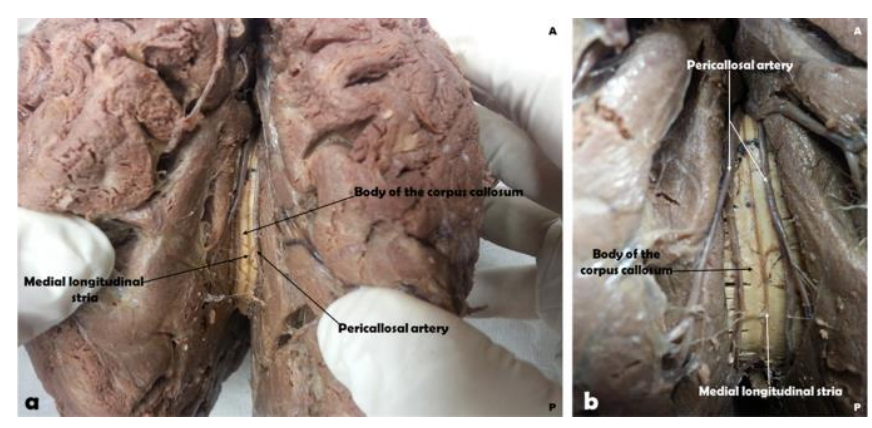

Şekil 1a-1b: Indusium griseum, stria longitudinalis medialis ve a. pericallosa (pericallosal artery) ile kaplanan corpus callosum'un gövdesini (body of the corpus callosum) gösteren anatomik kadavra beyin örneği.

Tablo I: Doku fiksasyonu metodu

\begin{tabular}{|c|c|c|}
\hline İşlem & $\begin{array}{c}\text { İşlem Süresi } \\
\text { (Önceki Yöntem) }\end{array}$ & $\begin{array}{l}\text { İşlem Süresi } \\
\text { (Çalışmada } \\
\text { Uygulanan) }\end{array}$ \\
\hline Çeşme suyunda & $24-48$ saat & $\begin{array}{c}\text { 6-8 saat veya bir } \\
\text { gece }\end{array}$ \\
\hline \%70’lik Alkol & - & 2 saat \\
\hline \%80’lik Alkol & 2 saat & 2 saat \\
\hline \%96'lık Alkol & 12 saat & 1 saat \\
\hline $\begin{array}{c}\text { \%100’lük (Absolü) } \\
\text { Alkol }\end{array}$ & $3 \times 2$ saat & 1 saat \\
\hline Ksilen (I)* & $\begin{array}{c}\text { Gözle (Şeffaflaşana } \\
\text { dek) }\end{array}$ & 15 dakika \\
\hline Ksilen (II) & - & 1 saat \\
\hline Parafin $(I)^{* *}$ & 2 saat & 30 dakika \\
\hline Parafin (II) & 2 saat & 1 saat \\
\hline
\end{tabular}

* dokuyu şeffaflama ve alkolü uzaklaştırmak için

** 60 derece etüv'de tutulmaktadır.

Elde edilen doku örnekleri tespit edici madde etkisinin azaltılması amacıyla Pbs'e alındı. Daha sonra histolojik aşamalar için daha elverişli olan \%4'lük formaldehit solüsyonu içerisine konuldu. $\mathrm{Bu}$ iki işlem de bir gece olarak uygulandı. Daha sonra doku takip aşamalarına alındı. Doku fiksasyon metodunu uygularken bazı revizyonlara gitme ihtiyacı duyuldu (Tablo 1). Doku takibinde dokular, ışık mikroskobunda transillüminasyon tekniğiyle ve HE ve LFB ile incelemeye uygun şekilde hazırlandı.

Tablo II: Hematoksilen-eosin boyama metodu

\begin{tabular}{|c|c|c|}
\hline İşlem & $\begin{array}{c}\text { İşlem Süresi } \\
\text { (Önceki Yöntem) }\end{array}$ & $\begin{array}{l}\text { İşlem Süresi } \\
\text { (Çalışmada } \\
\text { Uygulanan) }\end{array}$ \\
\hline Ksilen & $2 \times 10$ dakika & 1 saat \\
\hline $\begin{array}{c}\text { \%100'lük (Absolü) } \\
\text { Alkol }\end{array}$ & $2 \times 5$ dakika & 2 dakika \\
\hline \%96'llk Alkol & 3 dakika & 2 dakika \\
\hline \%80’lik Alkol & 3 dakika & 2 dakika \\
\hline \%70’lik Alkol & 2 dakika & 2 dakika \\
\hline Çeşme suyu & 2 dakika & 2 dakika \\
\hline Hematoksilen & 3-8 dakika & 15 dakika \\
\hline Asit alkol & daldır çıkar & daldır çıkar \\
\hline Amonyaklı su & daldır çıkar & daldır çıkar \\
\hline Çeşme suyu & 2 dakika & $2 \mathrm{dk}$ \\
\hline Eozin & $\begin{array}{c}30 \text { saniye-1 } \\
\text { dakika }\end{array}$ & 20 saniye \\
\hline \%80’lik Alkol & - & daldır çıkar \\
\hline \%96'lık Alkol & 2 dakika & daldır çıkar \\
\hline $\begin{array}{c}\text { \%100’lük (Absolü) } \\
\text { Alkol }\end{array}$ & $2 \times 2$ dakika & daldır çıkar \\
\hline Ksilen & $3 \times 10$ dakika & 1 saat \\
\hline Entellan ile KAPAT & & \\
\hline
\end{tabular}

Elde edilen dokular rutin histolojik metotlarla takip edilerek parafinde bloklandılar. $\mathrm{Bu}$ parafin bloklardan mikrotom ile rahat kesit alabilmek için bloklar bir süre buzdolabında soğumaya birakıldı. Daha sonra bloklar mikrotoma (Leica RM2145, Nussloch, Germany) yerleştirildi. Işık mikroskobik 
incelemelerde en iyi görüntüyü sağlamak amacıyla kesit kalınlıkları $5 \mu \mathrm{m}$ olarak ayarlandı. Kesilen dokular $38^{\circ} \mathrm{C}^{\prime}$ ye ayarlanmış benmari'ye alındı. Doku etrafındaki parafin sıcak suda açıldıktan sonra lam'lara alındı. Daha sonra lam'lar 1 gün kurumaya birakıldı. Cam şalelere yerleştirildi ve 25 derecede bir gece tutularak boyama işlemine hazır hale getirildi. Bloklardan alınan $5 \mu \mathrm{m}$ kalınlığındaki kesitler Luxol Fast Blue (Tablo 2) ve hematoksilen-eozin (Tablo 3) yöntemleriyle boyandılar. Hazırlanan preparatlardan gerekli görülen bölgelerin fotoğrafları, Nikon D3400 dijital kamera ve Nikon DS-L4 kamera kontrol ünitesiyle donatılan Olympus BX50 model mikroskopla çekildi ve kaydedildi.

Tablo III: Luxol fast blue boyama metodu

\begin{tabular}{|c|c|c|}
\hline İşlem & $\begin{array}{c}\text { İşlem Süresi } \\
\text { (Önceki } \\
\text { Yöntem) }\end{array}$ & $\begin{array}{l}\text { İşlem Süresi } \\
\text { (Çalışmada } \\
\text { Uygulanan) }\end{array}$ \\
\hline Ksilen & 1 saat & 1 saat \\
\hline $\begin{array}{c}\text { \%100'lük (Absolü) } \\
\text { Alkol }\end{array}$ & - & 2 dakika \\
\hline \%96'lık Alkol & 2 dakika & 2 dakika \\
\hline \%80’lik Alkol & - & 2 dakika \\
\hline \%70'lik Alkol & - & 2 dakika \\
\hline $\begin{array}{c}\text { Luxol fast } \\
\text { solüsyonunda }\end{array}$ & $\begin{array}{c}56 \text { derece'de } 1 \\
\text { gece }\end{array}$ & 60 derece'de 1 gece \\
\hline$\% 96$ lık Alkol & 2 dakika & - \\
\hline Distile su & daldır çıkar & daldır çıkar \\
\hline Lityum karbonat* & 10 saniye & 30 saniye \\
\hline \%70’lik Alkol & 2 dakika & - \\
\hline Distile su & daldır çıkar & - \\
\hline Cresyl echt violet & 30 saniye & 30 saniye- 1 dakika \\
\hline Distile su & daldır çıkar & daldır çıkar \\
\hline \%80’lik Alkol & - & daldır çıkar \\
\hline \%96'lık Alkol & 5 dakika & daldır çıkar \\
\hline $\begin{array}{c}\text { \%100'lük (Absolü) } \\
\text { Alkol }\end{array}$ & $2 \times 5$ dakika & daldır çıkar \\
\hline Ksilen & 1 saat & 1 saat \\
\hline
\end{tabular}

Entellan ile KAPAT $\quad * 100 \mathrm{ml}$ distile su için $0,05 \mathrm{gr}$
Kesitlere aynı zamanda daha sağlıklı bilgi almak için nörofilament protein kullanılarak immünohistokimyasal boyama yöntemi de uygulandı. Bu yöntem, Cathepsin $\mathrm{D}$ antijenik yapıya özel olup, primer antikor olarak AntiCathepsin D antibody [EPR3057Y] ve sekonder antikor olarak da Goat Anti-Rabbit IgG H\&L (Alexa Fluor® 488) kullanıldı17.

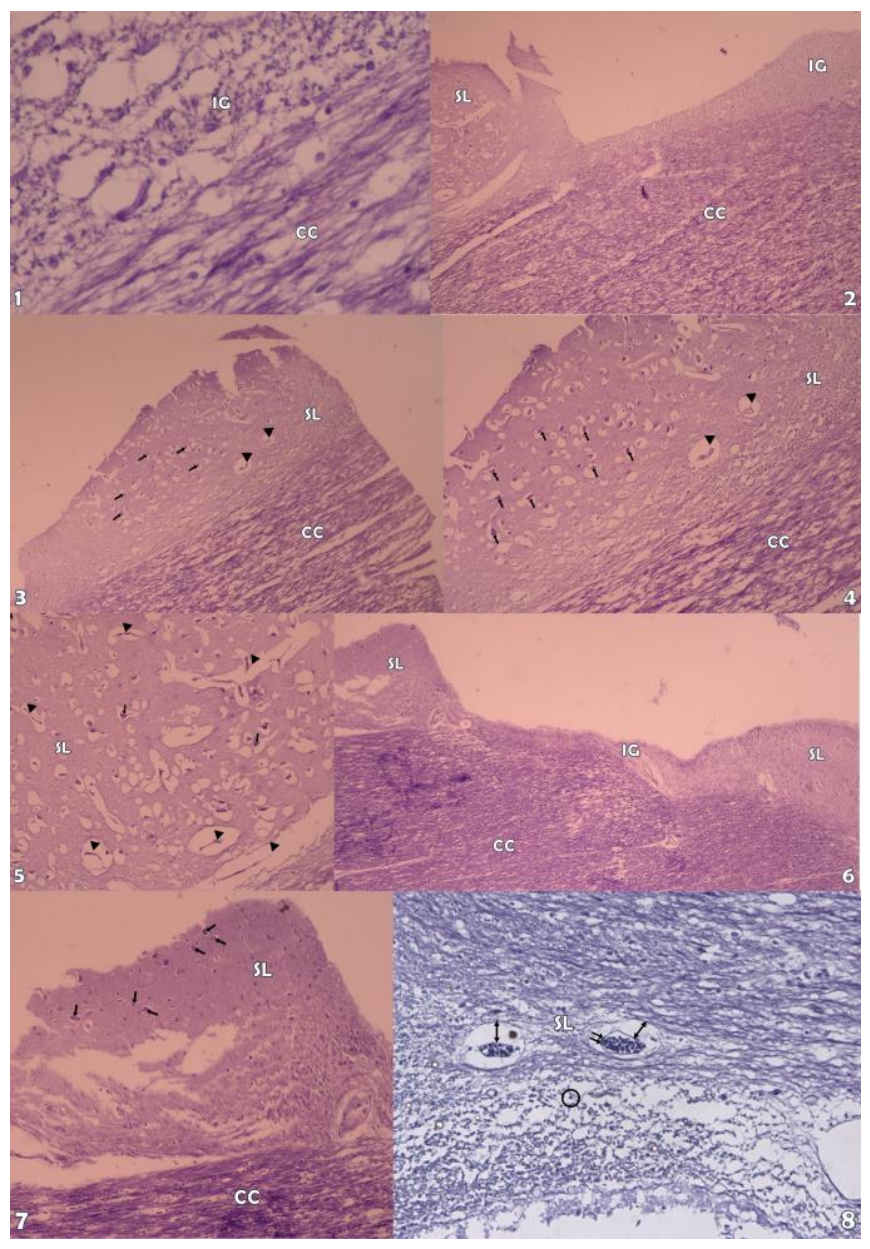

Şekil 2: Görüntüler gCC (1-5) ve tCC (6-8) alanlarından Luxol fast blue ile boyandıktan sonra alınmıștır. Ok, multipolar nöron; ok ucu, damar; çift yönlü ok, Virchow-Robin boşluğu; çift ok, vasküler endotel; daire, leptomeninks $(1,5$ ve $8, X 40 ; 2,3$ ve 6 , $\mathrm{X} 4 ; 4$ ve $7, \mathrm{X} 10$ ).

\section{BULGULAR}

SL, diseksiyon işlemleri sırasında CC'un üzerinde tespit edilip koronal kesitleri alındıktan sonra histolojik süreçler başlatıldı. Doku fiksasyonu yapıldıktan sonra boyama metodları kullanılarak SL'in morfolojik 
özelliklerinin tespiti yapıldı. LFB ile yaptığımız histolojik boyamada öncelikli olarak IG ve CC'un ayrımı yapıldı (Şekil 2/1). Daha sonra, gCC bölgesinden alınan doku örneğinde CC, IG ve SL'in görüntülenmesi gerçekleștirildi. İnceleme parafine yatırma işlemi yapılmadan tespit edilen lokalizasyona göre yapıldı. Bu üç farklı yapı bir pencereden fotoğraflandı (Şekil 2/2). SL içerisinde, IG ile karşılaştırıldığında, gözle görülür ölçüde multipolar nöronlar tespit edildi. Yine bu bölgede yer yer vasküler yapılar görüldü. Bunların daha önce diseksiyon esnasında CC'un üst yüzeyinde yer alan ve SL'in üzerinde dağılan a. cerebri anterior'un dalları olduğu düşünüldü (Şekil 2/3).

gCC kısmından alınan kesitte, CC ile SL arasındaki liflerin yoğunluğu ve görünümündeki farklılıklar daha açık bir şekilde görüldü. Multipolar nöronların belli bölgelerde daha yoğun bulundukları tespit edildi (Şekil 2/4). Sinir lifleri ile damarlar SL içinde aynı düzlemde bir uzanışa sahip olarak tespit edildi. Nöron ve damar yönünün tespit edilmesi mümkün olmadı (Şekil 2/5).

CC'un truncus bölgesinden alınan kesitinin LFB ile boyanmasından sonra elde edilen görüntüde CC, SLM'ler ve IG bir arada görüldü (Şekil 2/6). tCC seviyesinden alınan kesitte CC ve SL arasındaki ayrım çok net bir şekilde yapıldı (Şekil 2/7).

tCC seviyesinde, CC'dan geçip SL içerisinde seyrettiği bölgeden alınan bir kesitte damarların çevresinde oluşan Virchow-Robin boşluğu (VRB) örnekleri tespit edildi (Şekil 2/8).

\section{TARTIŞMA}

Yapılan kapsamlı kaynak taramalarında SLM ve SLL hakkında yapılmış çok az çalışma olduğu tespit edildi. Yapılan yetersiz sayıdaki çalışmalar da bu yapıların anatomik olarak tanımlamasını yapmak ve morfometrik ölçümler uygulamak, diseksiyon sonrasında tasvirlerini sağlamak ve tarihi arka planlarını ortaya çıkarmakla sınırlı kaldı. Son zamanlarda teknolojinin gelişmesi ile birlikte kullanılan görüntüleme tekniklerinde bile bu yapılar görüntülenemedi ve üzerlerindeki gizem ortadan kaldırılamadı.

İnsanlardaki SL'in boyut ve oluşum açısından morfolojik değişkenliğinin, kaynak taramasında ulaşılabilen mevcut verilere bakıldığında, tam olarak bilinmediği görüldü. Pavlovic ve ark. (2009) tarafından, otopsiden elde edilen 25 yetişkin insan beyni üzerinde bir çalışma gerçekleştirildi. SL'in genişlikleri ve aralarındaki mesafeler üç karakteristik yerden ölçüldü: gCC üstünde, tCC'nin orta kısmı üzerinde ve sCC'nin üzerinde. SLM'lar, SLL'lere nazaran daha belirgin fakat şekil ve ilişkileri açısından daha değişkendi. Yaklaşık olarak IG'un sagittal orta hattı boyunca uzandıkları görüldü. Çoğu durumlarda, aşağı yukarı simetrik özellikteydiler, zaman zaman kısmi olarak duplike olmuş, birleşmiş veya tamamlanmamış, yani kesintiliydi. Genel seyirleri açısından bakıldığında, birbirinden uzaklaştıkları posterior bölümü hariç, birbirlerine yakın olarak uzanmaktaydılar. SLL'ler, IG'un gyrus cinguli korteksinde devam ettiği yer olan CC'un oluğu içerisinde, yan tarafa doğru lokalize idi. SLL'ler, medial olanlara nazaran göze daha az çarpıyordu. İncelenen bütün durumlarda stria'ların birbirinden ayrı ve tek olarak göründükleri tespit edildi, sadece bazılarının kısmi olarak duplike oldukları görüldü10.

Görünümündeki farklılıklara ek olarak, SL aynı zamanda içerdikleri liflerin miktarına bağlı olarak daha az veya daha çok belirgin olabilirler. Stria'ların liflerinin çoğunluğunun, erken embriyolojik evrede, hippocampus'un yer değiştirmesi süresince beraberinde kaudale ve aşağıya doğru sürüklenen fornix'e ait lifler olduğu belirlendi ${ }^{10}$. Malobabic ve ark. (1988) tarafından, formalin ile fikse edilmiş 300 insan beyni üzerinde yapılan çalışmada, sadece bir beyinde olmak üzere varyasyon tespit edildi. $\mathrm{Bu}$ varyasyon da diğer beyinlerdeki 
eşdeğerlerine nazaran genişlemiş stria longitudinalis medialis'ti ${ }^{9}$. Arroyo-Guijarro ve ark. (1988) tarafından yapılan boğalarla ilgili mukayeseli bir çalışmada, SLM'in saldırgan davranışların kontrolü mekanizmasıyla ilişkisi olabileceği belirtildi. Aynı çalışmada SLM'in, evcil boğalara nazaran savaşçı boğalarda daha gelişmiş olduğu tespit edildi ${ }^{18}$.

Günümüzün görüntüleme alanında ilerleyen teknolojik altyapısına rağmen, SL'in radyolojik olarak görüntülenmesi tam olarak gerçekleştirilemedi. Yine de, difüzyon görüntülemenin (DTG), sağlıklı ve hastalık halindeki beyaz cevher farklılıklarını ölçmek için kullanılabilir ve lif oryantasyonu ve bağlantısı hakkında bilgi sağlayabilir olduğu yapılan çalışmalarda görüldü. Rollins'in (2013), gelişimsel gerilik ve otizm'li dört pediatrik hasta üzerinde yaptığı bir araştırmada, MRG'de CC’larının kalınlaştığı tespit edildi. Yine bu hastalarda DTG kullanılarak, cingulum'dan ayrllarak transvers kallosal liflere doğru dik olarak ilerleyen longitudinal supracallosal lifler yazar tarafından gösterildi ${ }^{19}$. Bizim çalışmamızda görülen SL'lerin, hem CC beyaz cevher'inin uzantıları olduğu hem de oblik ve longidutinal seyirlerinin olduğu görüldü. $\mathrm{Bu}$ tespitler, Rollins'in çalışmasında tespit edilen liflerin SL'e ait olma olasılığını kuvvetle muhtemel hale getirdi.

Nakada (1999), 20 sağlıklı gönüllü insan üzerinde MR görüntüleme tekniği kullanarak yaptığı çalışmasında, 16 gönüllüde IG tanımladı. Gyrus cinguli'nin altında kalan bölgenin, fornix'in crus'u seviyesinden yüksek çözünürlüklü koronal görüntüleri alındı. IG'un 4 tipik örneği ortaya çıkarıldı ${ }^{20}$. Jinkins tarafından, Nakada'nın elde ettiği görüntülerdeki IG olarak gösterilen yapının SLM olduğu iddia edildi. Ancak Nakada, IG'un gri cevher özelliğinden dolayı belirtilen görüntülerde bu gri cevher yapısının ayırt edilebileceğini ve bunun açlk olduğunu belirtti. Ayrıca imkânsız olmasa da, SL'i tanımlamanın çok daha zor olduğunu ileri sürdü; çünkü bu yapıların CC ile hemen hemen aynı yoğunluk özelliklerine sahip olduğunu söyledi. Bununla birlikte, Nakada, SL'in bazen IG'a bitişik küçük bir beyaz madde yapısı olarak ayırt edilebileceğini belirtti. Mark (2000), SLM'nin orta hatta yakın bir pozisyonda IG yüzeyi üzerinde küçük bir fokal yükselmeye neden olabileceği görüşünü ileri sürdü. İleride in vivo mikroanatomik MR görüntülemelerin daha da geliştirilmesiyle yapılacak çalışmaların, bu tartışmalı durumu bir açıklığa kavuşturacağı ümit edilmektedir ${ }^{20,21}$.

Fornix liflerinin, insanlarda normal hafıza ve öğrenme mekanizmalarının sürdürülmesi için vazgeçilmez olan formatio hippocampi ve area septalis arasındaki etkileşimi sağladığı çeşitli kaynaklarda belirtildi. Fornix'in az gelişmesi veya zedelenmesinin, hafıza eksikliği ile ilişkili olduğu ileri sürüldü. SL'lerin fonksiyonel yönleri net olarak bilinmemesine rağmen, fornix'ten ayrı bir şekilde ele alınması çok gerçekçi olmazdı. Fornix ile olan ilişkisinden dolayı SL'in de hafıza üzerinde fizyolojik olarak işlevsel bir rolünün olduğu düşüncesi kuvvetlendi. SL'in de dâhil olduğu septohippocampal projeksiyonların dorsal rotasının hafizayı kuvvetlendirme fonksiyonlarında önemli bir rol oynadıkları ile ilgili çeşitli çalışmalarda bazı kanıtlar sunuldu. Son 20 yıl içerisinde, IG ve SL araştırmalarında klinik yöntemler sunabilmek için iyi niyetli bazı çabalar gösterildi. Ne yazık ki bütün bu iyi niyetli çalışmalara rağmen çok büyük bir mesafe katedilemedi10,14,22-24.

Son zamanlarda, ventriculus tertius ile ventriculus lateralis ve diğer orta hat yapılarına ulaşmak için kısmi CC kesitinin alınması, büyük ölçüde kabul edilen ve genel olarak uygulanan bir yöntem haline geldi. Interhemisferik transkallosal yaklaşımın, SL'leri de kapsadığı ve onları da kestiği görüldü. Operasyon sonrası belirli bilişel rahatsızlıklar olmamasına rağmen, hastaların kısa dönem hafıza bozukluğu sergiledikleri tespit edildi. İstenmeyen yan etkileri ihtimali, transversal kallozotomi'den 
kaçınma ihtiyacı duyulmasını zorunlu hale getirdi. Sagittal, daha az aşina olunan kallozotomi'nin ise beyin cerrahları için daha cesaret verici bir yaklaşım olduğu görüşü benimsendi. SL'in insanlardaki fonksiyonları büyük oranda bilinmediğinden dolayı, kallozotomi sonrası sendromlarinda oynayabilecekleri rolün tartışmaya değer olduğu mevcut ve önceki çalışmalar ile görüldü ${ }^{10,25}$.

Assosiasyon lifleri, aynı beyin hemisferindeki merkezleri birbirine bağlayan liflerden meydana gelir ve lifleri sagittal yönde uzanır. Projeksiyon lifleri ise beyin korteksini daha aşağıdaki bölümlere ve medulla spinalis'e bağlar veya medulla spinalis ve beynin alt kısımlarını capsula interna'dan geçerek beyin korteksine bağlar. $\mathrm{Bu}$ lifler vertikal yönde seyreder ${ }^{5}$. Bizim çalışmamızda SL liflerinin oblik ve longitudinal olarak uzandıkları ve CC liflerini kestikleri görüldü. Seyirlerinden ve CC ile olan uzanımlarından dolayı kommissural lif olmadıklarını düşünüldü. SL'in, burdan yola çıkarak yapılacak daha detaylı çalışmalarında, assosiasyon liflerine mi yoksa projeksiyon liflerine mi dahil oldukları netleștirilebilir. Teknolojinin gelişmesiyle birlikte nöroradyolojik tekniklerle bu liflerin üç boyutlu olarak yönlerinin tespit edilmesi, bu yapılar hakkında merak ettiğimiz bu eksikliğin de giderilmesini sağlayacağı ümidindeyiz.

VRB, beyin parankimi yoluyla subaraknoid boşlukta seyreden damarların duvarlarını çevreler ${ }^{26}$. Bütün yaş gruplarında az sayıda görünür, fakat yaş ilerledikçe sıklığı artar. Daha ileri yaşlarda görülen depresyon, inflamasyon sırasında aktif multipl skleroz, miyotonik distrofi, Parkinson hastalığı ve laküner inme, beyaz cevher hiperintensiteleri ve vasküler demans şeklindeki küçük damar hastalığının dâhil olduğu birçok hastalık ve daha kötü bilişsel durumlar ile ilişkili olduğu bilinmektedir ${ }^{27}$. Alınan kesitler üzerinden bakıldığında yer yer mevcut çalışmada da VRB'ları tespit edildi. Bu bölgedeki önemi ve dilatasyonlarından elde edilecek çıarımlar için, görüntüleme teknikleri eşliğinde, daha detaylı bir yaklaşım gerektiği düşünüldü.

Çalışmamızda IG'da çok sayıda glial hücre tespit edildi; çalışma konusunun sınırlarının korunması amaciyla detaylı olarak incelenmesi gereği duyulmadı.

Çalışmamızda, CC'un gCC, tCC ve sCC olmak üzere 3 farklı bölgesinden kesit alındı. Fakat her ne kadar boyama protokolleri tarafımızca revize edilmiş olunsa dahi, muhtemelen kadavra beyinlerinin uzun süre formaldehit solüsyonlu havuzlarda tutulmasindan dolayi, 3 bölgeden de istenilen oranda dönüt alınamadı. Sonuç olarak bu bölümler arasında bir karşılaştırma yapılamadı. Belki ilerleyen yıllarda doku bütünlügü bozulmamış, taze kadavra beyinleri kullanılarak yapılacak çalışmalarda CC'un gCC, tCC ve sCC bölümleri arasında SLM ve SLL açısından morfolojik mukayeseler yapılabilir. Yine aynı şekilde, HE ve NF kullanılarak yapılan immünohistokimyasal boyama yöntemlerinden istenilen boyama dönütleri ve uygun görüntüler defalarca denenmesine rağmen elde edilemedi. Mevcut çalışma, bu sebeplerden ötürü LFB boyama metodu üzerinden takip edildi.

\section{SONUC}

Yapılan çalışmalarda görüldü ki, IG ve SL, özellikle radyolojik yaklaşımlarda, ayırt edilemeyebiliyor. İleride in vivo mikroanatomik MRG'lerin daha da geliștirilmesiyle birlikte bu ayrımın yapılmasının gerektiği düşünülmektedir. Histolojik olarak ilk defa CC, IG ve SL aynı görüntü üzerinde tespit edildi. SL'in lifleri, vasküler ve morfolojik yapısı belirtildi. Maalesef, bulgularımızla karşılaştırmak için SL'in görünümü ve detaylandırılmış morfolojik yapısı hakkında ulaşabildiğimiz mevcut literatür içerisinde herhangi bir veri bulamadık. Longitudinal assosiasyon liflerinin CC liflerine dik olarak girdikleri bilgisinin yanında, bizim 
çalışmamızda bu liflerin oblik ve longitudinal seyrettikleri görülmüştür. Buradan yola çıkarak SL liflerinin assosiasyon ya da projeksiyon liflerinden hangisine ait oldukları ile ilgili yapılacak üç boyutlu nöroradyolojik bir çalışma bu konu üzerindeki bilinmezleri ortadan kaldıracaktır. SL'in fornix ile olan bağlantısı ve buna paralel olarak hafizanın güçlendirilmesi ve emosyonların yönlendirilmesi üzerinde doğrudan ya da dolaylı bir bağlantısının olup olmadığı hakkında gerek görüntüleme tekniklerinin gerek fizyolojik yöntemlerin gelişmesini beklemek durumunda olduğumuz sonucuna varıldı. SL'in lif yapısı ve aksonal yoğunluğu göz önüne alındığında kallosotomi sonrası bu yapıya ait lif yapıları da kesileceğinden, kallosotomi sonrası görülen rahatsızlıkların SL açısından da ayrı olarak değerlendirilmesi gerekmektedir. Bu bölgenin nörokimyasal karakteri hakkında daha ileri seviyede sahip olunacak bilgi, fonksiyonu hakkında ipuçları elde etmemizi sağlayabilir. Çalışmamızda kullandığımız histolojik boyaların mevcut uygulama protokolleri, uzun süreli formaldehit solüsyonuna maruz kalan beyin dokusundan alınan kesitlerden uygun dönütler alabilmek için revize edildi. Umuyoruz ki, SL ile ilgili histolojik, immünohisto kimyasal ve anatomik yaklaşımlar ışığında yaptığımız bu girişim, bu konu üzerindeki bazı karanlık yönleri aydınlatacaktır. Böylece bizden sonra SL üzerinde çalışacak araştırmacıların istifadesine sunulmak üzere akademik bir hafıza oluşturacaktır.

Çıkar Çatışması Beyanı: Yazarlar çıkar çatışması olmadığını bildirmişlerdir.

Finansal Destek: Bu çalışma her hangi bir fon tarafından desteklenmemiștir.

Declaration of Conflicting Interests: The authors declare that they have no conflict of interest.

Financial Disclosure: No financial support was received.

\section{KAYNAKLAR}

1. Standring S, editor. Gray's anatomy: The anatomical basis of clinical practice, 40th edn. London: Churchill Livingstone Elsevier, 2008.

2. Taner D, editör. Fonksiyonel nöroanatomi, 10. bs. Ankara: Odtü Yayıncılık, 2007.

3. O'Rahilly R, Müller F. The embryonic human brain: An atlas of developmental stages, 3rd edn. USA: John Wiley \& Sons, 2006.

4. Shah A, Jhawar SS, Goel A. Analysis of the anatomy of the Papez circuit and adjoining limbic system by fiber dissection techniques. J Clin Neurosci. 2012; 19: 28998.

5. Arıncı K, Elhan A. Anatomi, 4. bs. Ankara: Güneş Kitabevi, 2006.

6. Di leva A, Fathalla H, Cusimano MD, Tschabitscher M. The indusium griseum and the longitudinal striae of the corpus callosum. Cortex. 2015; 62: 34-40.

7. Di leva A, Tschabitscher M, Baena RRY. Lancisi's nerves and the seat of the soul. Neurosurgery. 2007; 60: 563-8.

8. Cunningham DJ. Cunningham's textbook of anatomy, 12th edn. New York: W. Wood, 1818.

9. Malobabic S, Puskas L, Vela A. Enlarged medial longitudinal (supracallosal) stria in one human brain. Acta Biol Med Exp. 1988; 13: 87-90.

10. Pavlovic S, Stefanovic N, Malobabic S, et al. Longitudinal striae of the human fornix: shape, relations and variations. Surg Radiol Anat. 2009; 31: 501-6.

11. Swanson LW. Neuroanatomical Terminology: a lexicon of classical origins and historical foundations, 1st edn. USA: Oxford University Press, 2014.

12. Morgane PJ, Galler JR, Mokler DJ. A review of systems and networks of the limbic forebrain/limbic midbrain. Progress in neurobiology. 2005; 75: 143-60

13. Nieuwenhuys R, Voogd J, Van Huijzen C. The human central nervous system: a synopsis and atlas, 4 th edn. Berlin Heidelberg New York: Springer Science \& Business Media, 2007.

14. Tubbs RS, Prekupec M, Loukas M, Hattab EM, CohenGadol AA. The indusium griseum: anatomic study with potential application to callosotomy. Neurosurgery. 2013; 73: 312-6. 
15. Panikkath R, Panikkath D, Mojumder D, Nugent K. The alien hand syndrome. Proc (Baylor Univ Med Cent). 2014; 27: 219-20.

16. Bahuleyan B, Vogel TW, Robinson S, Cohen AR. Endoscopic total corpus callosotomy: cadaveric demonstration of a new approach. Pediatr Neurosurg. 2011; 47: 455-60.

17. Kashem MA, Etages HD, Kopitar-Jerala N, McGregor IS, Matsumoto I. Differential protein expression in the corpus callosum (body) of human alcoholic brain. J Neurochem. 2009; 110: 486-95.

18. Arroyo-Guijarro J, Prats-Galino A, Ruano-Gil D, CostaLlobet C. Comparative study of the medial longitudinal striae of the hippocampus (formerly called "nerves of Lancisi") in the fighting bull and domestic bull [in French]. Bulletin de l'Association des anatomistes. 1988; 72: 15-9.

19. Rollins NK. Diffusion imaging of the congenitally thickened corpus callosum. AJNR Am J Neuroradiol. 2013; 34: 660-5.

20. Nakada T. High-field, high-resolution MR imaging of the human indusium. AJNR Am J Neuroradiol. 1999; 20: 524-5.

21. Mark LP. Dr. Leighton Mark was invited to comment on this issue. AJNR Am J Neuroradiol. 2000; 21: 982-4.
22. Douet V, Chang L. Fornix as an imaging marker for episodic memory deficits in healthy aging and in various neurological disorders. Front Aging Neurosc. 2014; 6: 343.

23. Catani M, Dell'acqua F, De Schotten MT. A revised limbic system model for memory, emotion and behaviour. Neurosci Biobehav Rev. 2013; 37: 1724-37.

24. Magee KR, Olson RN. The effect of absence of the corpus callosum on the position of the hippocampus and on the formation of Probst's bundle. J Comp Neurol. 1961; 117: 371-82.

25. Schaller K, Cabrilo I. Corpus callosotomy. Acta Neurochir. 2016; 158: 155-60.

26. Kwee RM, Kwee TC. Virchow-Robin spaces at MR imaging. Radiographics. 2007; 27: 1071-86.

27. Biedroń A, Steczkowska M, Kubik A, Kaciński M2. Dilatation of Virchow-Robin spaces in children hospitalized at pediatric neurology department. Neurol Neurochir Pol. 2014; 48: 39-44. 